\title{
A large herbivore triggers alternative successional trajectories in the boreal forest
}

\author{
Bert Hidding, ${ }^{1,2,4}$ Jean-Pierre Tremblay, ${ }^{1,3}$ and Steeve D. Côté ${ }^{1}$ \\ ${ }^{1}$ Chaire de Recherche Industrielle CRSNG en Aménagement des Ressources de l'T̂le d'Anticosti, Département de Biologie and Centre \\ d'Études Nordiques, Université Laval, Québec G1V0A6 Canada \\ ${ }^{2}$ Department of Aquatic Ecology, Netherlands Institute of Ecology (NIOO-KNAW), Droevendaalsesteeg 10, 6708 PB, Wageningen, \\ The Netherlands \\ ${ }^{3}$ Centre d'Étude de la Forêt, Université Laval, Québec G1V0A6 Canada
}

\begin{abstract}
Alternative successional trajectories (AST) may result in multiple climax states within an ecosystem when disturbances affect colonization history. In the boreal forest, ungulates have been proposed to drive AST because, under herbivore pressure, preferred species may go extinct and apparent competition may benefit browsing-resistant species. Over a 15 -year period following logging, we tested whether deer herbivory altered plant species composition and whether the competitive advantage of resistant species was maintained following herbivore removal. We compared exclosures built immediately after logging with delayed exclosures built eight years later on Anticosti Island, Quebec, Canada. Although the palatable tree Betula papyrifera (paper birch) and some palatable herbs recovered in delayed exclosures, we observed legacies in both tree and herb cover. Woody regeneration in delayed exclosures was dominated by Picea glauca (white spruce), and Poaceae (grasses) were abundant in the field layer. Given that only early-successional species recovered, whereas latesuccessional broadleaf species and Abies balsamea (balsam fir) remained rare, succession may follow an AST after a limited browsing period during early succession.
\end{abstract}

Key words: alternative successional pathways; Anticosti Island, Quebec, Canada; community assembly; forest regeneration; herbivore resistance; herbivory; legacy effect; recruitment facilitation; resilience; succession; white-tailed deer.

\section{INTRODUCTION}

In a Clementsian view of ecology, vegetation succession is considered a directional process of species replacing each other toward a stable climax state (Clements 1916, Young et al. 2001). The mechanisms controlling succession under this scenario are primarily trade-offs between colonization ability and competitiveness, facilitation (Young et al. 2001), and negative frequency dependence, i.e., the decline of a species due to intraspecific competition and possibly parasites (Connell and Slatyer 1977). Herbivores at high density are regarded in this context as agents that may either slow or accelerate succession (Davidson 1993) by modulating these mechanisms; thus succession will in most cases resume its original rate toward a climax upon reduction of herbivore density. Although many systems may indeed behave consistently with a unidirectional type of succession (Cadenasso et al. 2002, Mathisen et al. 2010), there are circumstances under which more

Manuscript received 16 November 2012; revised 15 May 2013; accepted 24 May 2013. Corresponding Editor: P. M. Kotanen.

${ }^{4}$ Present address: Department of Ecosystem Research, Leibniz Institute for Freshwater Ecology and Inland Fisheries, Müggelseedamm 301, 12587, Berlin, Germany.

E-mail: abhidding@gmail.com than one outcome of succession is possible (Gleason 1926, Westoby 1989, Suding and Hobbs 2009).

According to this alternative view of succession, the structure and species composition of a climax may strongly depend on contingencies: presence or absence of certain species or functional groups may crucially determine consecutive colonization events, ultimately leading to disparate vegetation types. Such processes are termed alternative successional trajectories (AST, sensu Suding et al. 2004). We here define AST as the effect of a variation in community composition in an earlysuccessional stage leading to an altered climax species composition. AST hence involve legacy effects that persist until stand replacement. Legacy effects, in turn, are defined as an indirect effect persisting for a long time in the absence of the causal species' activities (sensu Cuddington 2012). AST do not necessarily lead to alternative stable states (ASS), because the latter would require a community to self-perpetuate by inhibiting changes in community composition even after stand replacement (cf. Fukami and Nakajima 2011). AST can come about in at least two ways: (1) through competitive effects of certain colonizers (initial floristic composition, sensu Egler 1954) that inhibit the recruitment of other species and (2) through local extirpation of a key constituent of the "normal" successional trajectory. Hence, for a given set of abiotic parameters, AST may 
lead to vastly different alternative states, as observed in aquatic systems (van Geest et al. 2007, Schooler et al. 2011), savannas (Seymour et al. 2010), and tropical forests (Norden et al. 2011). In a system where multiple alternative states potentially exist, herbivores may not only slow down or accelerate succession; but also they may change the direction of succession through their effect on key plant species (Seabloom and Richards 2003, Baskett and Salomon 2010). In a direct sense, herbivores may cause species extirpation through overgrazing (Augustine et al. 1998, McLaren et al. 2009). Indirectly, herbivores may mediate the relationships between intolerant and tolerant plants, providing an apparent competitive advantage to the latter (Holt 1977, Tremblay et al. 2007).

In forest ecology and global change research, it has been recognized relatively recently that ungulate herbivores might steer succession toward different states (Schmitz and Sinclair 1997, Olofsson et al. 2004, Tanentzap et al. 2012). This notion is being fueled at least partly by management issues related to high herbivore densities (Côté et al. 2004). In many ecosystems, large predators have declined, weakening topdown control such that herbivore populations have expanded dramatically (Estes et al. 2011). Conservative hunting regulations and changes in land use also contribute to maintain high populations of vertebrate herbivores (Côté et al. 2004). This, in turn, has significantly modified plant community composition and structure (e.g., Estes et al. 2011). In boreal and temperate forests, high densities of white-tailed deer (Odocoileus virginianus) and moose (Alces alces) have led to dominance of grasses, sedges, and ferns at the expense of browse-sensitive herbs and woody shrubs (Tremblay et al. 2006, Rooney 2009, Gosse et al. 2011). Such a field layer can be hard for woody species to penetrate and has therefore been termed a recalcitrant understory (Royo and Carson 2006). In addition, an increase in browseresistant tree species in the canopy has been attributed to white-tailed deer herbivory (Rooney et al. 2000, Horsley et al. 2003, Tremblay et al. 2007, Tanentzap et al. 2011). In line with an AST scenario, it has been shown that a state with a history of intense herbivory often appears difficult to reverse to an unaltered state. Long after significant reduction of cervid herbivore density, legacy effects have been reported (Tanentzap et al. 2009, Royo et al. 2010, Nuttle et al. 2011). In contrast, other systems have shown a strong recovery potential of key forest species after periods of high herbivore densities (e.g., Kuijper et al. 2010). Despite evidence that, under certain conditions, the impact of herbivory may be hard to reverse after herbivore reduction, a conclusive experimental test should compare succession after an initial disturbance (i.e., herbivory) under both presence and absence of the herbivore (Schmitz and Sinclair 1997).

Here, we test the alternative hypotheses (1) that the effects of intense deer herbivory on the community composition of herbs and woody species during regeneration are either reversible, with succession resuming its normal course after deer exclusion, or (2) that initial herbivory may lead to an alternative successional trajectory (AST). On Anticosti Island, this AST would imply dominance of Picea spp. Following the classification by Létourneau et al. (2009), we define dominance as $>75 \%$ of stems $(>1 \mathrm{~cm} \mathrm{dbh})$ being Picea spp. in the tree community 15 years after logging. To this end, we performed an herbivore removal experiment: we measured woody and field layer species composition in three different treatments over a period of 15 years after logging with: (1) original exclosures protecting regeneration directly after logging, (2) control plots, and (3) delayed exclosures constructed seven summer seasons after logging on plots previously accessible to deer. This delayed exclosure was aimed at testing whether a successional trajectory that was initiated under deer herbivory could be reversed to a successional trajectory observed in deer absence. By testing this reversibility of large-herbivore impacts on forest succession, we evaluate the long-term ecological effects of chronic browsing on forest composition and structure.

\section{Methods \\ Study site}

The experimental site was located on Anticosti Island $\left(7943 \mathrm{~km}^{2}\right)$ in the Gulf of St. Lawrence, Quebec, Canada $\left(49^{\circ} 06^{\prime}-49^{\circ} 95^{\prime} \mathrm{N}, 61^{\circ} 67^{\prime}-64^{\circ} 52^{\prime} \mathrm{W}\right)$. The climate on Anticosti is maritime, with a mean air temperature of $-13.6^{\circ} \mathrm{C}$ in January and $14.8^{\circ} \mathrm{C}$ in July, and mean annual precipitations of $328 \mathrm{~cm}$ as snow and $610 \mathrm{~mm}$ as rainfall (Environment Canada 2005; data are available online). ${ }^{5}$ The dominant boreal forest cover is part of the eastern balsam fir-paper birch region (Doucet and Côté 2009). Approximately 200 deer were introduced to Anticosti Island in 1896. In the absence of predators, the deer population became abundant $\sim 30$ years after introduction and remained abundant thereafter $\left(>20\right.$ deer $/ \mathrm{km}^{2}$; Potvin and Breton 2005). The forest communities of Anticosti have changed severely since white-tailed deer became abundant (Potvin et al. 2003). Although the island's forests were originally dominated by paper birch (Betula papyrifera Marsh.) and balsam fir (Abies balsamea (L.) and Mill.), these species are now being steadily replaced by white spruce (Picea glauca (Moench) Voss) and, to a lesser extent, black spruce (Picea mariana (Mill.) Britton, Sterns and Poggenb.). After forest logging, regeneration is sparse and consists almost exclusively of Picea spp. (Casabon and Pothier 2007), whereas the field layer is dominated by grasses (Poaceae) and sedges (Carex spp.) (Tremblay et al. 2006). The resulting relatively open landscape has been typified as spruce savanna (Tremblay et al. 2005).

${ }^{5}$ http://climate.weather.gc.ca/climateData/dailydata_e. html?Prov=QUE\&StationID $=8536$ 
In 1995, three clearcuts $\left(\sim 3 \mathrm{~km}^{2}\right.$ each) with regeneration protection were created by logging all trees with a diameter at breast height ( $\mathrm{dbh}$ ) of $\geq 9 \mathrm{~cm}$ in $A$. balsameadominated forest stands. Before logging, three experimental plots per clearcut were randomly selected $(n=9)$; the distance to the nearest forest edge varied between 50 and $600 \mathrm{~m}$. This variable was included to account for the possible role of the forest edge distance in post-harvest seedling establishment. In each plot, two circular subplots $10 \mathrm{~m}$ in diameter were systematically located $30 \mathrm{~m}$ apart. We tallied the regeneration and composition of the field layer therein in June 1995. To this end, we established five permanent sampling circles of $4 \mathrm{~m}^{2}$ in each subplot. Two clearcuts were logged between July and October, and one other was logged between October and November 1995. Immediately after logging, we excluded deer from one subplot (EXC); the other subplot was accessible to deer (CTL). Fences consisted of mesh wire and were $3 \mathrm{~m}$ high to avoid entry by deer in all seasons. In early May 2003, seven complete summer seasons after establishment of the initial exclosures, we added a third fenced subplot, hereafter designated as a delayed exclosure (DEL), $30 \mathrm{~m}$ from the center of the original exclosure or the control subplot and on a straight line with the other experimental subplots.

Sampling was performed in July of each sampling year: in 1995 before logging, in 2001, in 2003 after establishment of DEL, in 2008, and lastly in 2010. Regeneration was measured by counting all seedlings $(<30 \mathrm{~cm}$ height) and saplings (tall regeneration, $>30 \mathrm{~cm}$ height) of the encountered tree species within the sampling circles by height classes: $<5,5-30,31-60$, $61-100,101-200,201-300$, and $>301 \mathrm{~cm}$. In 2010, trees with $\mathrm{dbh}>1 \mathrm{~cm}$ were counted in 2-cm dbh classes (1-3 $\mathrm{cm}, 3-5 \mathrm{~cm}, 5-7 \mathrm{~cm}$, and so on). Percent ground cover of species in the field layer in $4-\mathrm{m}^{2}$ sampling circles was estimated visually. We identified most taxa at the species or genus level, but we identified grasses at the family level (Poaceae) and leptosporangiate ferns at the class level (Pteridopsida).

\section{Regeneration}

To assess the effect of the different herbivory treatments, mixed-effect Poisson models were applied to the counts of stems $(\mathrm{dbh}>1 \mathrm{~cm})$ within plots for the total of all stems and for P. glauca in 2010. Data on all other species were unsuitable for such analysis because, inside CTL plots, all counts for these species were zero: only Picea spp was found in CTL plots. Hence all other species were excluded. We used the lme4 package (Bates et al. 2011) in R ( $R$ Development Core Team 2010). Treatment and distance to the forest edge were predictor variables. Cutblock was a random term, and another random term was included at the level of each single observation to account for overdispersion in the count data (Elston et al. 2001). We applied likelihood ratio tests to models including fixed variables of interest and models without them to test whether treatments had effects that differed from zero. We also applied post hoc contrasts to differentiate between the different treatments by merging factor levels followed by likelihood ratio tests between models with merged vs. original factor levels (Crawley 2007).

To assess how early regeneration of key tree species $A$. balsamea, B. papyrifera, and $P$. glauca proceeded under the different herbivory regimes, we analyzed the density of seedlings ( $<30 \mathrm{~cm}$ height) and tall regeneration $(>30$ $\mathrm{cm})$, and mean stem height over time since the treatment started (1995 for CTL and EXC, 2003 for DEL) until seven (DEL) or eight (CTL, EXC) years after. We pooled data from sampling circles within subplots. Stem densities were modeled with Poisson error distributions using lme4 in $\mathrm{R}$, whereas mean stem heights were modeled with Gaussian error distributions using the nlme package (Pinheiro et al. 2011) in R. We preferred the nlme package in the latter case because it can fit heterogeneous error structures, whereas lme4 cannot. For all models, fixed variables of interest were exclosure treatment (categorical) and time since the treatment started, in years (using year instead of a linear variable from $t=0$ to 8 years after the beginning of the treatment yielded identical results; analysis not shown). Random factors were block, plot, and subplot. In the Poisson models on stem density, an individual-level random effect was included to account for overdispersion. In the Gaussian models on mean stem height, response variables were transformed (log, square-root, or fourth-root) to achieve a normal distribution of the residuals. Shapiro tests were applied to test whether the residuals were normally distributed and Bartlett's test was applied to verify homogeneity of variances. If the latter test turned out to be significant, a heterogeneous variance structure was fit to account for variance heterogeneity. To test for the significance of variables and factor levels, likelihood ratio tests were applied in the same manner as for the total stem counts.

\section{Field layer}

We limited the analysis of the field layer to the 12 most frequently occurring taxa in each treatment. This resulted in a total of 16 taxa over all treatments. We compared abundance of these species between treatments by adding up all of the cover percentages within each subplot and calculating treatment effect size per plot as follows (adapted from Petermann et al. [2008]):

$$
\text { Effect size }=\log \left(\operatorname{cover}_{1}+1\right)-\log \left(\operatorname{cover}_{2}+1\right) .
$$

Here, cover 1 and cover 2 denote different treatments. The log was taken of the ratio between treatments because it is symmetric around 0 . The addition of 1 , the smallest nonzero value in the data, was added to account for 0 values (Quinn and Keough 2002, Bolker 2011). To compare field layer species composition after logging in protected plots vs. plots chronically browsed over the whole study period, we calculated effect sizes for the treatments EXC over 
CTL (both in 2001 and 2003). To estimate the effect of herbivore exclusion immediately after logging or after an initial period of herbivory using a similar exclusion period, we compared field layer composition between DEL $(2008,2010)$ and EXC (2001, 2003). Lastly, we assessed the divergence of the field layer of DEL from the control CTL after a period of 5-7 years (both in 2008 and 2010). In all comparisons, we pooled the data from the two years that were two years apart and fitted a mixed-effects model for each species individually using the lme4 package in R. Species that were absent from both treatments in a given plot were excluded from the analysis. Effect size was the response variable and species was the predictor variable. Block was included as a random variable. A Shapiro-Wilk test was performed to check whether data points within species were normally distributed, which was the case. Following Bates et al. (2011), 10000 Markov chain Monte Carlo samples were generated of the parameter estimates (function mcmcsamp in lme4), and 0.95 highest posterior density (HPD) intervals were calculated from these samples. Effects were considered significant when HPD intervals did not overlap with zero.

\section{RESUlts}

\section{Regeneration}

Deer exclusion had a positive impact on stem density $(>1 \mathrm{~cm} \mathrm{dbh}) 15$ years after logging with the highest stem density in EXC $\left(12.8 \times 10^{3} \pm 2.3 \times 10^{3}\right.$ stems/ha; mean \pm SE; Appendix: Table A1), intermediate densities in $\operatorname{DEL}\left(6.8 \times 10^{3} \pm 0.9 \times 10^{3} \mathrm{stems} / \mathrm{ha}\right)$, and the lowest in CTL $\left(4.2 \times 10^{3} \pm 0.4 \times 10^{3}\right.$ stems/ha). The density of Picea glauca stems was highest in DEL $\left(5.8 \times 10^{3} \pm 1.9\right.$ $\times 10^{3}$ stems/ha; Appendix: Table A1, Fig. 1), which was marginally different from CTL $\left(3.6 \times 10^{3} \pm 1.2 \times 10^{3}\right.$ stems/ha) and significantly different from EXC $(2.5 \times$ $10^{3} \pm 0.8 \times 10^{3} \mathrm{stems} / \mathrm{ha}$ ). Inside the original exclosures, tree species composition was dominated by Betula papyrifera (36\%), P. glauca (28\%), Populus tremuloides Michx. (trembling aspen, 15\%), and Abies balsamea (14\%) (Fig. 1). We also observed occasional Prunus pensylvanica L. f. (pin cherry) and Picea mariana. We observed one stem of Sorbus americana Marsh. (American mountain ash). In the control plots, the only tree species present with saplings $(\mathrm{dbh}>1 \mathrm{~cm})$ were $P$. glauca $(88 \%)$ and P. mariana (12\%). The same species were dominant in DEL ( $P$. glauca, $83 \%$ ) and P. mariana, $12 \%$; Fig. 1), but with some B. papyrifera (5\%). A. balsamea and $P$. tremuloides saplings were very rare, totaling less than $1 \%$ of the species pool in DEL (Fig. 1).

The change in density of $P$. glauca was similar among the CTL and EXC treatments, both for seedlings and tall regeneration (Fig. 2; Appendix: Table A2). The low number of $P$. glauca seedlings in the DEL treatment is related to the low recruitment of this species in cutblocks eight years after logging, whereas the initial regeneration of $P$. glauca was already well established. Mean height

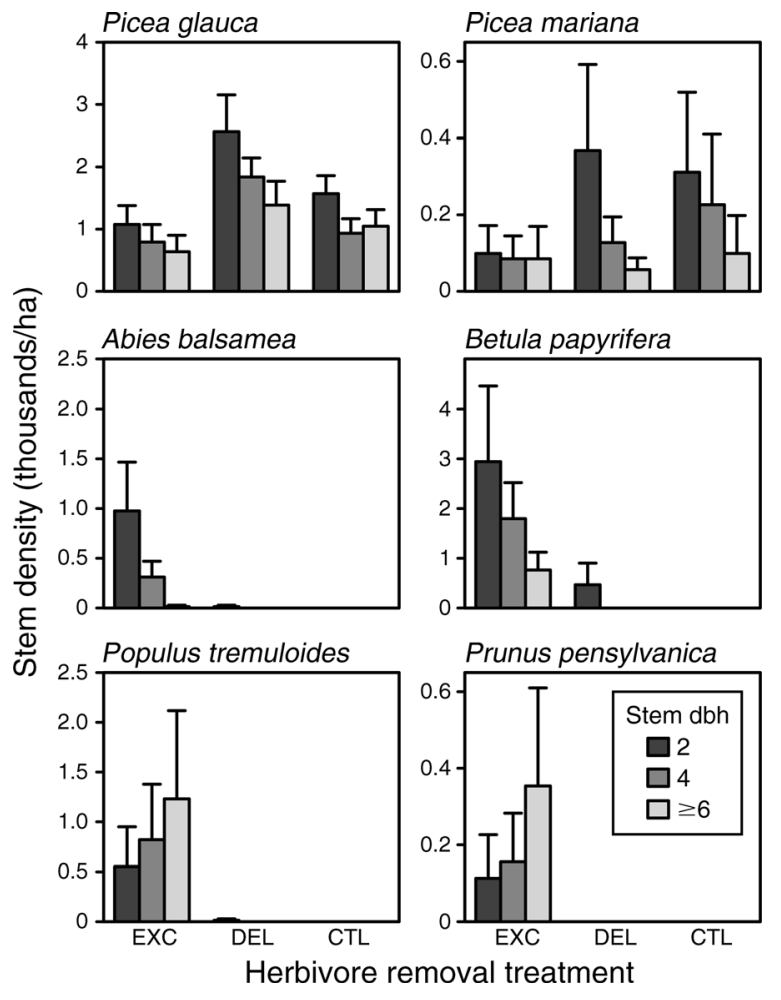

FIG. 1. Stem density (mean $+\mathrm{SE}$ ) of saplings in summer 2010 by size class (dbh) in a herbivore removal experiment on Anticosti Island, Quebec, Canada. Density of stems of the six most dominant species with $\mathrm{dbh}>1 \mathrm{~cm}$ is shown for three treatments: in exclosures established in 1995 (EXC), delayed exclosures in 2003 (DEL), and control plots (CTL). Note the different scales on the $y$-axes.

increased steadily to $2 \mathrm{~m}$, overgrowing woody species except B. papyrifera in DEL.

The density of tall $A$. balsamea regeneration $(>30 \mathrm{~cm})$ eight years after exclusion was one order of magnitude lower in DEL than in EXC (Fig. 2; Appendix: Table A2). It was also an order of magnitude lower than the density of $P$. glauca saplings; A balsamea only reached the density of $P$. glauca saplings in EXC. Seedling densities were also much lower in DEL than in EXC and in DEL than in CTL at $t=0$ (Fig. 2). We observed a steady decline of seedlings with recruitment into the sapling stage in EXC. This decline was also present in CTL even if there was no recruitment in $>30 \mathrm{~cm}$ classes, a situation that we attribute to heavy browsing on seedlings in CTL. Hence, initial conditions were already unfavorable for $A$. balsamea at the time of delayed exclosure establishment in 2003. Mean stem height of $A$. balsamea, on the other hand, did not show any significant differences between delayed and original exclosures (Appendix: Table A2).

Tall regeneration of B. papyrifera (stems $>30 \mathrm{~cm}$ ) was virtually only found in EXC and DEL (Fig. 2). The recruitment of tall regeneration increased with time and was not significantly affected by the timing of deer 

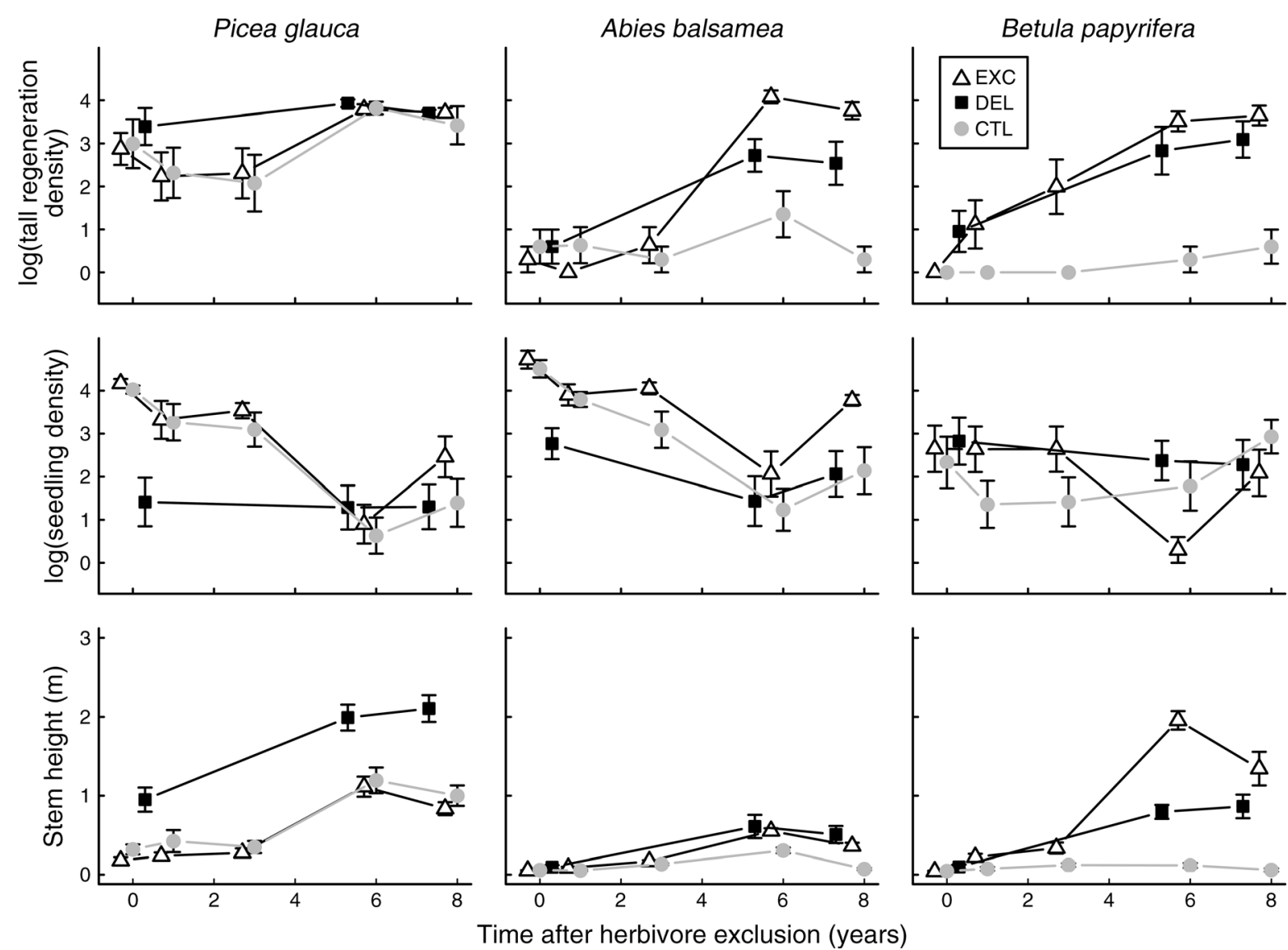

FIG. 2. Stem density (mean $\pm \mathrm{SE}$ ) of tall regeneration $(>30 \mathrm{~cm})$ and of seedlings $(<30 \mathrm{~cm})$, and height $(\mathrm{mean} \pm \mathrm{SE})$ for the three most dominant tree species over time in an exclosure experiment on Anticosti Island. Year 0 is the year of logging for the control (CTL) and the original exclosures (EXC), and the moment of disturbance removal for the delayed exclosures (DEL). Stem density data (originally measured as stems/ha) are $\log _{10}$-transformed.

exclusion and EXC and DEL were indistinguishable (Appendix: Table A2). We found no significant effect of distance to the forest edge for saplings. Seedling density, however, was significantly affected by distance to the forest edge, with higher densities of seedlings in plots far from the forest edge. Mean stem height of $B$. papyrifera varied significantly among treatments: height (time $\times$ treatment interaction) was largest in EXC and smallest in CTL. Height after delayed exclusion (DEL) was also lower than in the original exclosures (EXC), but higher than in CTL (Appendix: Table A2).

\section{Field layer}

The composition of the field layer community differed widely between the CTL and EXC treatments six (2001) and eight (2003) years after deer exclusion, with mostly browse-sensitive species dominant in EXC and resistant plant species in CTL. EXC plots exhibited high densities of Chamerion angustifolium, Rubus idaeus, leptosporangiate ferns (Pteridopsida), Cornus canadensis, and Maianthemum canandense (Fig. 3A). All of these species except ferns were significantly more dominant in EXC than in CTL (Fig. 4). In the CTL treatment, however, the field layer was dominated by grasses (Poaceae) and Cirsium arvense at that time (Fig. 3A); C. arvense was significantly more dominant in CTL than in EXC, but Poaceae cover was highly variable (Fig. 4A). In 2008 and 2010, the same species that dominated the field layer in EXC earlier were still abundant (Fig. 3B). However, the cover of most species (except $C$. canadensis) had contracted. The CTL plots also showed diminished cover of field layer species, but with grasses still relatively abundant (Fig. 3B). The field layer in the delayed exclosures 5-7 years after herbivore removal was dominated by a mix of species dominant in initial exclosure and control plots: Poaceae, C. canadensis, and C. angustifolium (Fig. 3B).

Comparing the field layer of the delayed exclosure 5-7 years after fencing with the exclosures 6-8 years after establishment showed that the browse-resistant species were more abundant in delayed exclosures than in original exclosures (Fig. 4B). DEL was dominated by Poaceae, $C$. arvense, and $C$. canadensis. In original exclosures, $C$. angustifolium and $R$. idaeus were more abundant than in delayed exclosures (Fig. 4B). 
Comparing delayed exclosures with control plots in 2008 and 2010, however, revealed that percent ground cover of $C$. angustifolium, $C$. canadensis, and $M$. canadense was higher in delayed exclosures than in control plots (Fig. 4C). Hence, in terms of the composition of the field layer cover, the delayed exclosures did exhibit a higher abundance of some of the browse-sensitive species. Hence, the delayed exclosures had a mix of both browse-sensitive and browseresistant field-layer species.

\section{DisCUSSION}

To test whether intense herbivory during early succession had lasting legacy effects on the vegetation composition of a boreal forest, we performed an herbivore removal experiment in which we contrasted continuous browsing pressure following a clearcut to both immediate exclusion and to delayed herbivore exclusion. After 15 years of herbivore exclusion, original exclosures were dominated by dense stands of primarily broadleaf species, whereas the control plots exhibited relatively low tree stem densities entirely dominated by Picea spp. The latter community type, which is rather open in terms of tree cover, contained higher cover of Cirsium arvense and mainly Poaceae, and can therefore be typified as a spruce savanna. The delayed exclosures, however, did not converge to a totally herbivoreunaffected trajectory or to a spruce savanna, but rather took an intermediate trajectory initially, with a mix of browse-resistant and sensitive species in the field layer and Betula papyrifera and Picea spp. as the most dominant woody species. In the long term, B. papyrifera will probably disappear from the canopy, given its relatively short life span (Safford et al. 1990), and we expect Picea spp. to become dominant. Given the high abundance of Picea glauca in the delayed exclosures that exceeded our operational definition of dominance (75\%) among late-successional tree species, we consider the vegetation to deviate from a state without deer and thus to exhibit characteristics of an alternative successional trajectory (AST) after eight years of continued browsing.

The AST scenario is supported by the observation that $P$. glauca continued to benefit from early successful recruitment that was most likely caused by selective browsing on preferred species; 15 years after logging, the stem density ( $>1 \mathrm{~cm} \mathrm{dbh}$ ) of $P$. glauca was highest in the delayed exclosures and lowest in the original exclosures. In addition, in the delayed exclosures Abies balsamea stem density was far below what would be expected for a species originally dominant on the island. A. balsamea lacks a seed bank and normally builds up a seedling bank instead (Safford et al. 1990). This seedling bank, the advance regeneration, experiences high mortality at ambient deer density on Anticosti Island (Tremblay et al. 2007, Hidding et al. 2012). As a consequence, seedling density became strongly compromised after eight years of deer presence.
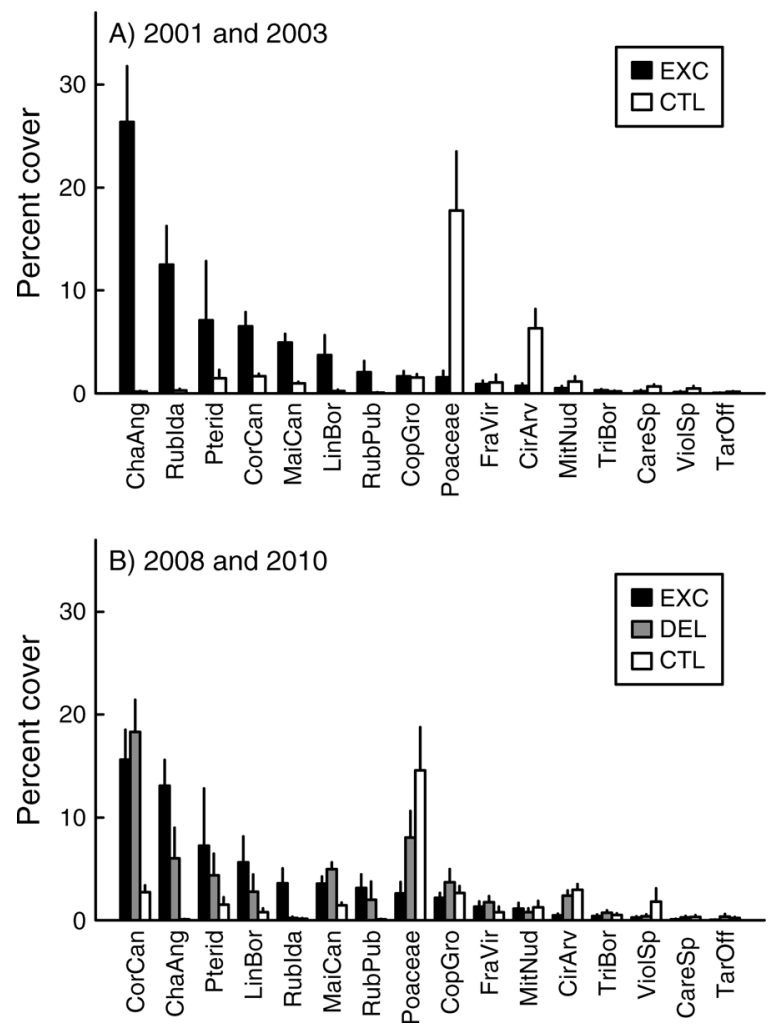

FIG. 3. Percent ground cover (mean $+\mathrm{SE}$ ) of the 16 most dominant herbs in experimental plots in cut blocks logged in 1995 on Anticosti Island, Quebec, (A) in 2001 and 2003 combined for exclosures established in 1995 (EXC) vs. control plots (CTL) and (B) in 2008 and 2010 combined for the original exclosures (EXC), the delayed exclosures (DEL, established in 2003), and the control plots (CTL). Plant species codes are: CareSp, Carex sp.; CirArv, Cirsium arvense; CopGro, Coptis trifolia; CorCan, Cornus canadensis; ChaAng, Chamerion angustifolium; FraVir, Fragaria virginiana; Poaceae; LinBor, Linnaea borealis; MaiCan. Maianthemum canadense; MitNud, Mitella nuda; Pterid, leptosporangid ferns; RubIda, Rubus idaeus; TarOff, Taraxacum officinale; TriBor. Trientalis borealis; ViolSp, Viola sp.

However, among early-successional species, not all regeneration in the delayed exclosures represented the legacy of intense ungulate herbivory: considerable regeneration of $B$. papyrifera, which is otherwise heavily browsed by white-tailed deer, may indicate that $B$. papyrifera can maintain fitness after sustaining herbivore damage (tolerance sensu Rosenthal and Kotanen 1994). B. papyrifera stem density was similar in original exclosures and delayed exclosures after comparable herbivore exclusion periods. It may be that $B$. papyrifera recruited from small, wind-dispersed seeds in the delayed exclosures, as it did in the original exclosures. However, a more likely scenario is the persistence of a relatively high number of $B$. papyrifera seedlings until the time of delayed exclosure establishment, suggesting that $B$. papyrifera seedlings may survive high browsing pressure by storing carbon in roots and stems. The seedlings may thereafter grow vigorously once deer herbivory stops. Indeed, it was 


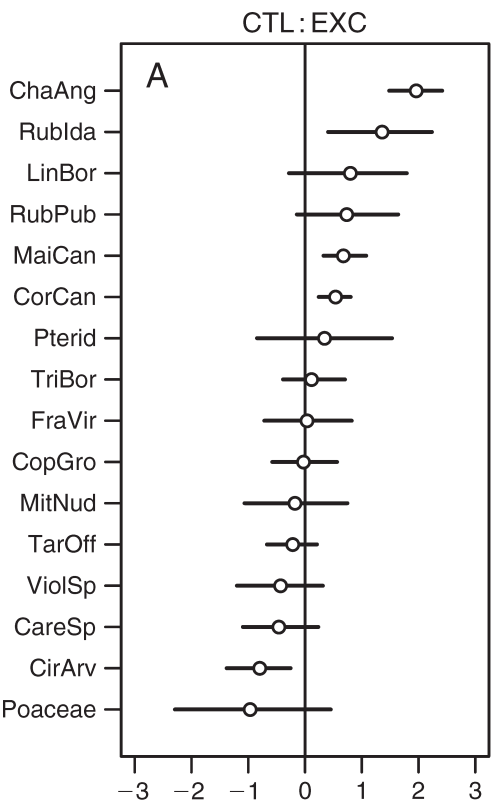

Relative abundance shift

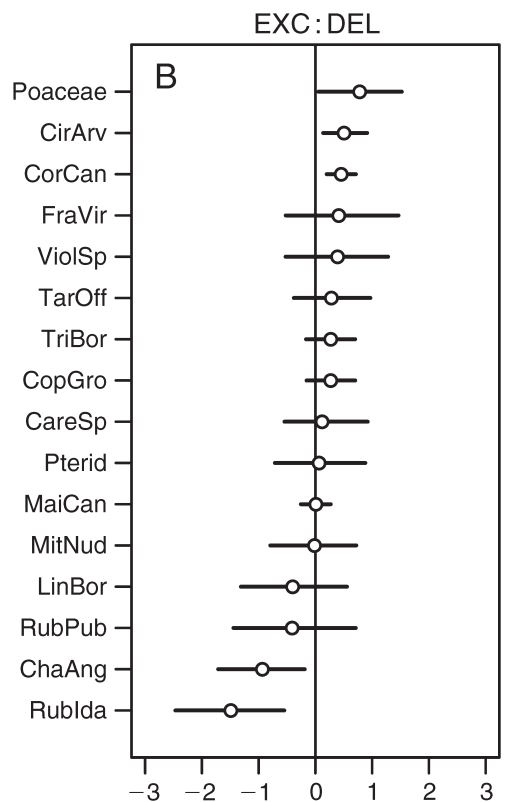

Relative abundance shift

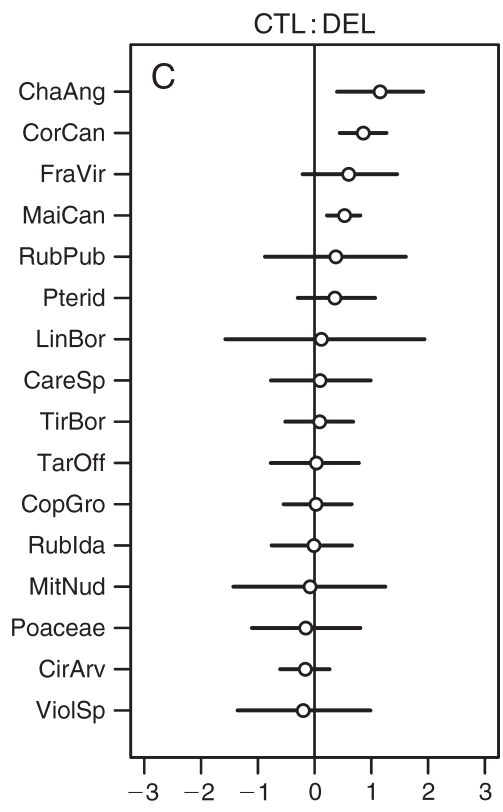

Relative abundance shift

FIG. 4. The relative difference in abundance between treatments for the 16 most dominant herbs in a disturbance removal experiment. (A) The effect size of species in the exclosures (EXC) vs. control plots (CTL) within a pooled data set from 2001 and 2003. (B) Effect size of species in the delayed exclosures in 2008 and 2010 (DEL) vs. early exclosures (EXC) in 2001 and 2003. (C) Effect size of species in delayed exclosures (DEL) vs. the control plots (CTL) in 2008 and 2010. Error bars represent $95 \%$ highest posterior density intervals calculated from 10000 Markov chain Monte Carlo samples from a mixed-effects model fit for each individual species (lme4 package; Bates et al. 2011). For an explanation of species abbreviations, see Fig. 3.

shown that Betula species may tolerate severe clipping over prolonged periods (Kinnaird 1974, Palacio et al. 2008). Although regeneration in the delayed exclosures was a mix between browse-sensitive and resistant species, we expect the climax to be dominated by the only abundant late-successional species: Picea spp.

A similar mixed response was observed in the field layer. Browse-resistant taxa such as Cirsium arvense and possibly Poaceae were still observed at high densities 5-7 years after browsing was halted, indicating a browsing legacy. Poaceae may form a recalcitrant layer (sensu Royo et al. 2010) that may inhibit colonization by certain woody plant species (Rooney 2009, Tanentzap et al. 2012). Such recalcitrant layers may, however, be permeable to other species (George and Bazzaz 1999). Certain browse-sensitive field-layer species indeed established in delayed exclosures, although Chamerion angustifolium was present in much lower densities than it was immediately after logging in the absence of deer. Other species, such as Maianthemum canadense and Cornus canadensis, also recovered partially relative to control plots. These are all species that can make up a significant part of white-tailed deer diets (Skinner and Telfer 1974, Dostaler et al. 2011). These recoveries therefore indicate resilience of some of the browsed species. Poaceae cover, which may have been higher in delayed exclosures, did not provide enough of a recalcitrant layer to inhibit the increase of browsesensitive herbs and B. papyrifera.
The balance between legacy effects and community resilience in both woody regeneration and field-layer composition may depend on two time variables. The first time variable is the historical exposure of the environment to deer. If deer had been present for a prolonged period of time, browse-sensitive species simply may have been absent from the species pool, making recovery impossible. On the other hand, had our experiment taken place at the time deer first became abundant on the island in the 1930s (Marie-Victorin and Rolland-Germain 1969), we may have observed lower resilience, because the most browse-sensitive species would still have been abundant at that time. In particular, advance regeneration of $A$. balsamea may have been present at the time of logging, causing a stronger $A$. balsamea dominance than found in our experiment. The second important time variable is the seven-year period we chose to let regeneration take its course in the presence of deer. A shorter period would have allowed higher $A$. balsamea densities and perhaps more broadleaved species to establish. A longer time period would have resulted in A. balsamea absence, possibly lower $B$. papyrifera densities, and higher ground cover of recalcitrant species. We chose this period of seven years as it provides enough time to expect plant community changes due to deer herbivory (Tremblay et al. 2006), while at the same time competition among saplings for canopy space is ongoing 
and woody species are still at or under browse height (Hidding et al. 2012).

Notwithstanding, the contrast between plots protected immediately after logging, control plots, and delayed exclosures is striking. Deer browsing during the first decade after logging may determine field layer and future canopy composition (Tremblay et al. 2006, 2007, McLaren et al. 2009), and may thus have drastic consequences for the remainder of succession. In the case of Anticosti Island, canopy dominance may entirely shift from $A$. balsamea toward Picea spp., forming an alternative successional trajectory. Many studies have found support for legacy effects (sensu Cuddington 2012) of large herbivores on vegetation (e.g., Tanentzap et al. 2009, Nuttle et al. 2011). Nonetheless, to our knowledge, ours is the first comparison of herbivore absence, presence, and absence after presence simultaneously in the boreal forest. We found that a brief period of herbivory can indeed shift succession in a direction that is distinct from successional trajectories under herbivore absence. Local extirpation of A. balsamea played an important role. Delayed herbivore exclusion positively affected browse-resistant $P$. glauca, but allowed recovery of $B$. papyrifera as well as palatable species in the field layer. However, because $B$. papyrifera and field-layer species have relatively short life spans, the effect of delayed exclusion on the climax should not be underestimated. We therefore stress the crucial role that ungulate herbivores may play during early regeneration after a stand-replacing disturbance.

\section{ACKNOWLEDGMENTS}

We thank the Natural Sciences and Engineering Research Council of Canada-Produits Forestiers Anticosti Industrial Chair and the Ministry of Natural Resources and Wildlife of Québec for funding. SEPAQ Anticosti provided logistical support. We thank D. Pothier, F. Potvin, C. Dussault, S. de Bellefeuile, G. Laprise, C. Casabon, D. Duteau, M. Renière, G. Darmon, J. Faure-Lacroix, J. Gingras, and other volunteers for crucial assistance in the field, as well as numerous students who helped collecting data over the years. We thank G. Daigle for statistical advice and G. Darmon, M. Schrama, A. Tanentzap, and an anonymous reviewer for valuable comments on an earlier version of the manuscript.

\section{Literature Cited}

Augustine, D. J., L. E. Frelich, and P. A. Jordan. 1998. Evidence for two alternate stable states in an ungulate grazing system. Ecological Applications 8:1260-1269.

Baskett, M. L., and A. K. Salomon. 2010. Recruitment facilitation can drive alternative states on temperate reefs. Ecology 91:1763-1773.

Bates, D., M. Maechler, and B. Bolker. 2011. lme4: Linear mixed effects models using $\mathrm{S} 4$ classes. $\mathrm{R}$ package version 0.999375-42. R Foundation for Statistical Computing, Vienna, Austria. http://cran.r-project.org/package=lme4/

Bolker, B. M. 2011. Ecological models and data in R. Princeton University Press, Princeton, New Jersey, USA.

Cadenasso, M. L., S. T. A. Pickett, and P. J. Morin. 2002. Experimental test of the role of mammalian herbivores on old field succession: community structure and seedling survival. Journal of the Torrey Botanical Society 129:228-237.

Casabon, C., and D. Pothier. 2007. Browsing of tree regeneration by white-tailed deer in large clearcuts on
Anticosti Island, Quebec. Forest Ecology and Management 253:112-119.

Clements, F. E. 1916. Plant succession: an analysis of the development of vegetation. Carnegie Institution of Washington, Washington, D.C., USA.

Connell, J. H., and R. O. Slatyer. 1977. Mechanisms of succession in natural communities and their role in community stability and organization. American Naturalist 111: $1119-1144$

Côté, S. D., T. P. Rooney, J.-P. Tremblay, C. Dussault, and D. M. Waller. 2004. Ecological impacts of deer overabundance. Annual Review of Ecology, Evolution, and Systematics 35:113-147.

Crawley, M. J. 2007. The R book. John Wiley, Chichester, West Sussex, UK.

Cuddington, K. 2012. Legacy effects: the persistent impact of ecological interactions. Biological Theory 6:203-210.

Davidson, D. W. 1993. The effects of herbivory and granivory on terrestrial plant succession. Oikos 68:23-35.

Dostaler, S., J.-P. Ouellet, J.-F. Therrien, and S. D. Côté. 2011. Are feeding preferences of white-tailed deer related to plant constituents? Journal of Wildlife Management 75:913-918.

Doucet, R., and M. Côté, editors. 2009. Manuel de foresterie. Éditions MultiMondes, Quebéc, Quebéc, Canada.

Egler, F. E. 1954. Vegetation science concepts I. Initial floristic composition, a factor in old-field vegetation development. Plant Ecology 4:412-417.

Elston, D. A., R. Moss, T. Boulinier, C. Arrowsmith, and X. Lambin. 2001. Analysis of aggregation, a worked example: numbers of ticks on red grouse chicks. Parasitology 122:563569.

Estes, J. A., et al. 2011. Trophic downgrading of planet Earth. Science 333:301-306.

Fukami, T., and M. Nakajima. 2011. Community assembly: alternative stable states or alternative transient states? Ecology Letters 14:973-984.

George, L. O., and F. A. Bazzaz. 1999. The fern understory as an ecological filter: emergence and establishment of canopytree seedlings. Ecology 80:833-845.

Gleason, H. A. 1926. The individualistic concept of the plant association. Bulletin of the Torrey Botanical Club 53:7-26.

Gosse, J., L. Hermanutz, B. McLaren, P. Deering, and T. Knight. 2011. Degradation of boreal forests by non-native herbivores in Newfoundland's National Parks: recommendations for ecosystem restoration. Natural Areas Journal 31: 331-339.

Hidding, B., J.-P. Tremblay, and S. D. Côté. 2012. Survival and growth of balsam fir seedlings and saplings under multiple controlled ungulate densities. Forest Ecology and Management 276:96-103.

Holt, R. D. 1977. Predation, apparent competition, and the structure of prey communities. Theoretical Population Biology 12:197-229.

Horsley, S. B., S. L. Stout, and D. S. DeCalesta. 2003. Whitetailed deer impact on the vegetation dynamics of a northern hardwood forest. Ecological Applications 13:98-118.

Kinnaird, J. W. 1974. Effect of site conditions on the regeneration of birch (Betula pendula Roth and B. pubescens Ehrh.). Journal of Ecology 62:467-472.

Kuijper, D. P. J., B. Jędrzejewska, B. Brzeziecki, M. Churski, W. Jẹdrzejewski, and H. Żybura. 2010. Fluctuating ungulate density shapes tree recruitment in natural stands of the Białowieża Primeval Forest, Poland. Journal of Vegetation Science 21:1082-1098.

Létourneau, J.-P., A. Bard, and J. Lambert. 2009. Normes de cartographie écoforestière. Troisième inventaire écoforestier. Ministère des Ressources Naturelles et de la Faune Forêt, Québec. Direction des inventaires forestiers, Québec, Québec, Canada.

Marie-Victorin, F., and F. Rolland-Germain. 1969. Flore de l'Anticosti-Minganie. Presses de l'Université de Montréal, Montréal, Quebéc, Canada. 
Mathisen, K. M., F. Buhtz, K. Danell, R. Bergström, C. Skarpe, O. Suominen, and I. L. Persson. 2010. Moose density and habitat productivity affects reproduction, growth and species composition in field layer vegetation. Journal of Vegetation Science 21:705-716.

McLaren, B., L. Hermanutz, J. Gosse, B. Collet, and C. Kasimos. 2009. Broadleaf competition interferes with balsam fir regeneration following experimental removal of moose. Forest Ecology and Management 257:1395-1404.

Norden, N., R. C. G. Mesquita, T. V. Bentos, R. L. Chazdon, and G. B. Williamson. 2011. Contrasting community compensatory trends in alternative successional pathways in central Amazonia. Oikos 120:143-151.

Nuttle, T., E. H. Yerger, S. H. Stoleson, and T. E. Ristau. 2011. Legacy of top-down herbivore pressure ricochets back up multiple trophic levels in forest canopies over 30 years. Ecosphere 2:1-11.

Olofsson, J., S. Stark, and L. Oksanen. 2004. Reindeer influence on ecosystem processes in the tundra. Oikos 105:386-396.

Palacio, S., A. J. Hester, M. Maestro, and P. Millard. 2008. Browsed Betula pubescens trees are not carbon limited. Functional Ecology 22:808-815.

Petermann, J. S., A. J. F. Fergus, L. A. Turnbull, and B. Schmid. 2008. Janzen-Connell effects are widespread and strong enough to maintain diversity in grasslands. Ecology 89:2399-2406.

Pinheiro, J., D. Bates, S. DebRoy, D. Sarkar, and the R Development Core Team. 2011. nlme: linear and nonlinear mixed effects models. $\mathrm{R}$ package version 3.1-101. R Foundation for Statistical Computing, Vienna, Austria. http://cran.r-project.org/web/packages/nlme/

Potvin, F., P. Beaupré, and G. Laprise. 2003. The eradication of balsam fir stands by white-tailed deer on Anticosti Island, Québec: a 150-year process. Ecoscience 10:487-495.

Potvin, F., and L. Breton. 2005. Testing two aerial survey techniques on deer in fenced enclosures - visual doublecounts and thermal infrared sensing. Wildlife Society Bulletin 33:317-325.

Quinn, G. P., and M. J. Keough. 2002. Experimental design and data analysis for biologists. Cambridge University Press, Cambridge, UK.

R Development Core Team. 2010. R: a language and environment for statistical computing. Vienna, Austria. http://www.r-project.org

Rooney, T. P. 2009. High white-tailed deer densities benefit graminoids and contribute to biotic homogenization of forest ground-layer vegetation. Plant Ecology 202:103-111.

Rooney, T., R. McCormick, S. Solheim, and D. Waller. 2000. Regional variation in recruitment of hemlock seedlings and saplings in the upper Great Lakes, USA. Ecological Applications 10:1119-1132.

Rosenthal, J. P., and P. M. Kotanen. 1994. Terrestrial plant tolerance to herbivory. Trends in Ecology and Evolution 9: $145-148$

Royo, A. A., and W. P. Carson. 2006. On the formation of dense understory layers in forests worldwide: consequences and implications for forest dynamics, biodiversity, and succession. Canadian Journal of Forest Research 36:13451362.

Royo, A. A., S. L. Stout, D. S. DeCalesta, and T. G. Pierson. 2010. Restoring forest herb communities through landscapelevel deer herd reductions: Is recovery limited by legacy effects? Biological Conservation 143:2425-2434.
Safford, L. O., J. C. Bjorkbom, and J. C. Zasada. 1990. Betula papyrifera Marsh. paper birch. Pages $158-171$ in R. M. Burns and B. H. Honkala, editors. Silvics of North America. U.S. Department of Agriculture, Washington, D.C., USA.

Schmitz, O. J., and A. R. E. Sinclair. 1997. Rethinking the role of deer in forest ecosystem dynamics. Pages 201-223 in W. J. McShea, J. Rappole, and B. Underwood, editors. The science of overabundance: deer ecology and population management. Smithsonian Institution Press, Washington, D.C., USA.

Schooler, S. S., B. Salau, M. H. Julien, and A. R. Ives. 2011. Alternative stable states explain unpredictable biological control of Salvinia molesta in Kakadu. Nature 470:86-89.

Seabloom, E. W., and S. A. Richards. 2003. Multiple stable equilibria in grasslands mediated by herbivore population dynamics and foraging behavior. Ecology 84:2891-2904.

Seymour, C. L., S. J. Milton, G. S. Joseph, W. R. J. Dean, T. Ditlhobolo, and G. S. Cumming. 2010. Twenty years of rest returns grazing potential, but not palatable plant diversity, to Karoo rangeland, South Africa. Journal of Applied Ecology 47:859-867.

Skinner, W. R., and E. S. Telfer. 1974. Spring, summer, and fall foods of deer in New Brunswick. Journal of Wildlife Management 38:210-214.

Suding, K. N., K. L. Gross, and G. R. Houseman. 2004. Alternative states and positive feedbacks in restoration ecology. Trends in Ecology and Evolution 19:46-53.

Suding, K. N., and R. J. Hobbs. 2009. Threshold models in restoration and conservation: a developing framework. Trends in Ecology and Evolution 24:271-279.

Tanentzap, A. J., D. R. Bazely, S. Koh, M. Timciska, E. G. Haggith, T. J. Carleton, and D. A. Coomes. 2011. Seeing the forest for the deer: Do reductions in deer-disturbance lead to forest recovery? Biological Conservation 144:376-382.

Tanentzap, A. J., L. E. Burrows, W. G. Lee, G. Nugent, J. M. Maxwell, and D. A. Coomes. 2009. Landscape-level vegetation recovery from herbivory: progress after four decades of invasive red deer control. Journal of Applied Ecology 46: 1064-1072.

Tanentzap, A. J., K. J. Kirby, and E. Goldberg. 2012. Slow responses of ecosystems to reductions in deer (Cervidae) populations and strategies for achieving recovery. Forest Ecology and Management 264:159-166.

Tremblay, J.-P., J. Huot, and F. Potvin. 2006. Divergent nonlinear responses of the boreal forest field layer along an experimental gradient of deer densities. Oecologia 150:78-88.

Tremblay, J.-P., J. Huot, and F. Potvin. 2007. Density-related effects of deer browsing on the regeneration dynamics of boreal forests. Journal of Applied Ecology 44:552-562.

Tremblay, J.-P., I. Thibault, C. Dussault, J. Huot, and S. D. Côté. 2005. Long-term decline in white-tailed deer browse supply: Can lichens and litterfall act as alternative food sources that preclude density-dependent feedbacks? Canadian Journal of Zoology 83:1087-1096.

van Geest, G. J., H. Coops, M. Scheffer, and E. H. van Nes. 2007. Long transients near the ghost of a stable state in eutrophic shallow lakes with fluctuating water levels. Ecosystems 10:36-46.

Westoby, M. 1989. Selective forces exerted by vertebrate herbivores on plants. Trends in Ecology and Evolution 4: 115-117.

Young, T. P., J. M. Chase, and R. T. Huddleston. 2001. Community succession and assembly. Ecological Restoration 19:5-18.

\section{Supplemental Material}

\section{Appendix}

Statistical tables of the effects of immediate and delayed deer exclusion on woody regeneration on Anticosti Island, Quebec, Canada. (Ecological Archives E094-263-A1). 